\title{
Peran Gender dalam Keluarga Nelayan Tradisional dan Implikasinya pada Model Pemberdayaan Perempuan di Kawasan Pesisir Malang Selatan
}

\section{Gender Role in Traditional Fisherman Family and the Implication on Women Empowerment Model in Coastal Area of South Malang}

\author{
Hany Handajani ${ }^{1 *}$, Rahayu Relawati ${ }^{2}$, Eko Handayanto ${ }^{3)}$
}

1 Jurusan Perikanan Universitas Muhammadiyah Malang, Jln. Raya Tlogomas no. 246, Malang 65144; Jurusan Agribisnis Universitas Muhammadiyah Malang, Jln. Raya Tlogomas no. 246, Malang 65144; ${ }^{3}$ Jurusan Manajemen Universitas Muhammadiyah Malang, Jln. Raya Tlogomas no. 246, Malang 65144; Email : hannyhandajani.umm@gmail.com

\begin{abstract}
Abstrak. Nelayan tradisional masih mempertahankan cara penangkapan ikan, bekerja tanpa inovasi teknologi, tanpa dukungan modal kuat, tanpa kelembagaan usaha yang mapan. Tujuan jangka panjang penelitian adalah terbinanya nelayan tradisional berdasarkan perspektif gender. Dalam jangka pendek perlu dirumuskan metode pembinaan perempuan khususnya dan keluarga nelayan tradisional pada umumnya setelah melalui serangkaian analisis gender. Penelitian dilakukan di pesisir Sendangbiru, Malang Selatan. Sempel keluarga nelayan tradisional ditentukan secara random. Data diambil melalui wawancara terstruktur, wawancara mendalam dan observasi partisipatif. Data dianalisis secara deskriptif dan dengan analisis gender metode Harvard. Rumusan metode pembinaan keluarga nelayan tradisional disusun melalui Focussed Group Duscussion (FGD). Hasil penelitian :1) Aktivitas nelayan pada kegiatan melaut semua dilakukan oleh laki-laki, keterlibatan perempuan hanya pada persiapan bekal makanan, dan kegiatan pasca tangkap yaitu pelelangan. Jadi disini masih ada pembagian kerja gender berdasarkan kepantasan pekerjaan perempuan dan laki-laki. 2) Akses dan kontrol laki-laki dominan pada sumberdaya penangkapan ikan dan kelompok nelayan. Akses dan kontrol perempuan dominan pada sumberdaya domestik dan sumberdaya pengolahan ikan. 3) Manfaat sumberdaya nelayan sudah dinikmati bersama diantara anggota keluarga nelayan, baik laki-laki maupun perempuan. Dampak yang diraskan dari sibuknya aktivitas nelayan adalah kekurangan perhatian orang tua terhadap proses belajar anak di rumah, kesehatan dan sanitasi lingkungan. 4) Metode pembinaan nelayan terdiri dari pembinaan keluarga dan pembinaan usaha. Model pembinaan keluarga difokuskan pada pembinaan anak, kesehatan, sanitasi lingkungan dan kesetaraan gender. Pembinaan usaha pada pengolah abon terdiri dari manajemen usaha, teknik pengolahan dan pemasaran, manajemen pemasaran, membangun jaringan usaha, promosi dan mencari pelanggan.
\end{abstract}

Kata kunci : nelayan tradisional, aktivitas melaut, aktivitas pasca tangkap ikan, pembinaan

Abstract. Traditional fishermen still maintain fishing and working witout technological inovation, good financial support, and good management. The long term aim of theis researc was to train the traditional fishermen based on gender perspectives. In the short term, after a series of gender analysis, it is important to formulate method for training women, in particular, and the fishermen families in general. This research was conducted in Sendangbiru, Southern part of Malang. The sample was selected in a random basis. The data were elicitied by using structured interview, in depth interview, and participatory observation. Meanwhile, the data were analyzed descripitely, by means of a gender research method, called Harvard. The formulation of the training for fishermen families was constructed through a Focused Group Discussion (FGD). The research results showed that: 1) The fishermen's fishing activities were done by men, and the participation of women was limited to the food preparation and to the post fishing, called fish auction. In this case, there was still some gender based work share.

2) While man dominantly accessed and controlledthe resources in fishing anda fisherman group, women had a dominant role in the resources of domestic and fish processing. 3) The fishermen resources had been 
preceived beneficial by all family members, both men and women. However their bustle affected on childrens ummanageable education, less attention to health environment sanitation. and 4) The training model for fisherman comprised familiy and business training. The former training was ampahisized on the education of children, health and environtment sanitation, and gender equity. Meanwhile, the latter was focused on the shredded fish (abon) processing, wich consisted of business management, processingand packaging techniques, marketing management, business network building, promotion and custemer searching.

Keywords : traditional fishing; fishing activity; post-fishing activities; coaching

\section{Pendahuluan}

Nelayan adalah tenaga kerja yang melakukan aktivitas produksinya dengan cara berburu ikan di laut. Perkembangan teknik penangkapan ikan modern dengan diperkenalkannya motorisasi telah mengakibatkan nelayan terbagi menjadi dua kategori, yakni nelayan tradisional dan nelayan modern. Nelayan tradisional adalah nelayan yang masih mempertahankan cara penangkapan sederhana dengan mengandalkan tanda-tanda alam dalam menentukan lokasi penangkapan ikan, tanpa inovasi teknologi, tanpa dukungan modal yang kuat, dan tanapa kelembagaan usaha yang mapan.

Upaya meningkatkan kesejahteraan masyarakat pesisir didasrkan pada baseline study yang memotret aktivitas mereka secara holistik. Pengabaian pada distribusi kerja yang terpilah berdasarkan gender seringkali mengakibatkan sasaran program pembinaan yang tidak tepat, sehingga mengakibatkan kegagalan. Fakta di lapang menunjukkan bahwa peran perempuan di sektor perikanan tidak kecil, terutama pada kegiatan pasca penangkapan ikan. Demikan juga kegiatan pemasaran dan pengelolaan pendapatan mereka lebih banyak dikelola perempuan. Namun perempuan jarang mendapatkan akses pada sumberdaya atau lembaga yang dapat meningkatkan kemampuan mereka.

Hampir seluruh nelayan yang melakukan penangkapan ikan dengan pola tradisional banyak melibatkan pihak laki-laki dan perempuan. Tenaga kerja perempuan dalam pola penangkapan ikan secara tradisonal memegang peran yang sangat penting karena dapat memberikan sumbangn pendapatan yang cukup besar. Nelayan tradisonal perempuan dapat melakukan penjualan ikan segar secara langsung di pasar dan melakukan proses pengawetan ikan dengan metode pengawetan basah dan kering.

Kawasan pesisir di wilayah Malang selatan mempunyai karakteristik masyarakat nelayan tradisional sebagaimana digambarkan pada uraian di atas. Tempat Pelelangan Ikan (TPI) yang mengindikasikan berjalannya roda pemasaran ikan berlokasi di Pantai Sendangbiru. Namun disisi lain kesjahteraan nelayan seperti berjalan di tempat.

Fakta bahwa nelayan tradisional adalah mereka yang notabene berpendidikan rendah, apalagi nelayan perempuan mengakibatkan penguasaan teknologi, kemampuan manajemen dan wawasan untuk kreativitas mereka sangat randah, maka perlu dilakukan model pembinaan berdasarkan baseline study terhadap analisis gender yang dapat menjadi soslusi dalam pembinaan nelayan tradisional.

Nelayan tradisional adalah mereka yang notabene berpendidikan rendah, apalagi nelayan perempuan mengakibatkan penguasaan teknologi, kemampuan manajemen dan wawasan untuk kreativitas mereka sangat randah, maka perlu dilakukan model pembinaan berdasarkan baseline study terhadap analisis gender yang dapat menjadi soslusi dalam pembinaan nelayan tradisional.

Tujuan dari Penelitian ini adalah untuk menyusun rumusan metode pembinaan perempuan khususnya dan keluarga nelayan tradisional pada umumnya untuk meningkatkan pendapatan mereka dan kontribusi pada pendapatan subsektor perikanan. Untuk mencapai tujuan ini secara bertahap dirinci tujuan khusus sebagai berikut :1) Menganalisis aktivitas gender dalam kegiatan keluarga nelayan tradisional, terdiri dari kegiatan produktif dan reproduktif. 2) Menganalisis profil gender dalam akses dan kontrol pada sumberdaya dan lembaga yang mendukung peningkatan kesejahteraan nelayan tradisonal. 3) Menganalisis manfaat dan dampak aktifitas nelayan tradisional dalam penangkapan dan pasca penangkapan ikan bagi keluarga mereka. 4) Menganalisis model pembinaaan perempuan nelayan tradisional untuk meningkatkan kesejahteraan mereka. 
Kegunaan penelitian diharapkan dapat memberikan kontribusi berikut : 1) Menjadi masukan bagi perencana dan pengambil kebijakan pembangunan sektor kelautan dan perikanan yang lebih responsive gender, terutama dalam memberdayakan kaum perempuan dalam partisipasinya dibidang keseharian. 2) Menambah pengetahuan bagi ilmuan dan peneliti yang tertarik pada studi yang mengupayakan pemberdayaaan perempuan dalam sektor kelautan dan perikanan baik pada tingkat rumah tangga maupun tingkat nasional.

\section{Metode Penelitian \\ Pemilihan Lokasi Penelitian}

Penelitian ini dilakukan di Kabupaten Malang, dengan mengambil lokasi di daerah pesisir pantai selatan. Lokasi ditentukan di kawasan pesisir pantai Sendangbiru dengan pertimbangan bahwa disana terdapat TPI yang mengindikasikan berjalannya system pemasaran ikan. Dengan demikian analisis gender dapat dilakukan pada aspek yang lebih luas terutama pada aktivitas yang lebih beragam, akses yang lebih banyak pada lembaga di luar keluarga dan manfaat sumberdaya.

Penentuan Populasi Sampel

Populasi penelitian adalah keluarga nelayan tradisional di pesisir Malang Selatan, dengan berbagai kategori yaitu juragan darat, juragan laut, Anak Buah Kapal, makelar (blantik) dan pemodal (pengambek). Sampel ditentukan secara random pada masing-masing kategori. Jumlah responden sebanyak 50 keluarga nelayan ditambah beberapa responden kunci seperti dari perangkat desa, ketua kelompok, pengurus PPI, dan TPI.

\section{Teknik Pengumpulan Data}

Teknik pengumpulan data yang digunakan dalam penelitian ini, mencakup: 1) Penggalian informasi awal dari pustaka dan publikasi yang tersedia. 2) Penggunaan kuesioner semi terbuka. Kuesioner terdiri dari sejumlah pertanyaan tertutup disertai alternative jawaban yang sudah disediakn untuk dipilih responden, dan pertanyaan terbuka jawabannya diserahkan pada responden sepenuhnya. 3) Wawancara dengan responden dilakukan untuk mendapatakan informasi secara mendalam (indepth interview), digunakan untuk mencari jawaban pertanyaan yang tidak tercantum dalam kuesioner. 4) Observasi partisipatif, yaitu pengamatan dan keterlbatan secara langsung pada aktivitas nelayan tradisional pada kegiatan pasca tangkap ikan.

\section{Metode Analisis}

Analisis yang digunakan adalah analisis deskriptif dan Gender Framework Analysis (GFA) dari Harvard. Analisis deskriptif dilengkapi dengan uraian verbal, tabel silang dan perhitungan matematis sederhana seperti rata-rata dan persentase. Analisis Hardvard ini dilakukan pada data aktivitas, akses dan control serta manfaat dan dampak pada keluarga nelayan tradisioanal.

Profil aktvitas digunakan untuk melihat aktivitas gender pada keluarga nelayan tradisioanal dalam kegiatan produktif pada penengkapan dan pasca tangkap ikan serta kegiatan reproduktif berkaitan dengan kegiatan domestik. Profil akses dan control digunakan untuk melihat siapa dan bagaiaman kesempatan untuk mengakses sumberdaya di dalam dan diluar rumah yang berkaitan dengan kegiatan nelayan dan kemampuan untuk mengontrolnya. Profil manfaat dan dampak bertujuan untuk menggambarkan manfaat dan dampak yang dinikmati oleh anggota rumah tangga dari sumberdaya terkait dengan kegiatan nelayan tradisioanal. Rumusan metode pembinaan keluarga nelayan tradisional disusun melalui Focussed Group Duscussion (FGD). Peserta FGD adalah pihak-pihak yang terkait dengan aktivitas nelayan tradisional (stakeholder) meliputi : Petugas PPI, nelayan tradisional, TPI, keloompok nelayan, dan pemerintah desa setempat.

\section{Hasil dan Pembahasan \\ Gambaran Umum Daerah Penelitian}

Kawasan panatai Sendangbiru masuk dalam wilayah Dusun Sendangbiru, Desa Tambakrejo, Kecamatan Sumbermanjing Wetan, Kabupaten Malang. Batas-batas wilayahnya adalah sebelah barat 
Rowotrate-Sitiarjo (hutan), sebelah Utara Desa Sitiarjo (hutan), sebelah Timur Dusun Tambakrejo dan sebelah Selatan Samudra Indonesia. Ketinggiaan tempat $15 \mathrm{~m}$ dpl dengan suhu 25 --35 $5^{\circ}$. Jarak desa dengan ibukota kecamatan $30 \mathrm{~km}$ dan dengan ibukota propinsi $150 \mathrm{~km}$.

Jumlah penduduknya sebanyak 2688 jiwa, terdiri dari laki-laki 1358 jiwa dan perempuan 1330 jiwa dengan $70 \%$ mayoritas berprofesi sebagai nelayan, $25 \%$ sebagai petani dan $5 \%$ pedagang.

Sebagian besar penduduknya hanya lulusan Sekolah Dasar dengan perincian detailnya adalah belum lulus SD 345 jiwa, lulus SD 1844 jiwa, SMP 174, SLTA 45, sarjana 7 dan selebihnya sebanyak 173 jiwa adalah usia belum seokolah. Data tersebut menunjukkan bahwa hamper 70\% penduduk Sendangbiru hanya mengenyam pendidikan SD. Tentu hal ini adalah tingkat pendidikan yang sangat rendah untuk seseorang dapat mengembangkan wawasan dan inovasi teknologi baru.

Gambaran masyarakat lainnya adalah pada keluarga petani, banyak diantara perempuan mereka menjadi Tenaga Kerja Wanita di luar negri. Tahun ini tercatat 25 warga Sendangbiru yang menjadi buruh migran di berbagai Negara tujuan terutama Hongkong.

Kategori Nelayan, berikut adalah deskripsi pekerjaan pada masing-masing kategori nelayan. Juragan darat adalah pemilik perahu yang tidak ikut melaut, dan membiayai semua biaya melaut, terdiri dari solar dan bahan makanan yang dibutuhkan selama melaut. Biaya bias mencapai Rp 1.000.000-Rp 1.500.000 per perahu sekali melaut. Perolehan ikan setelah dipotong biaya melaut dubagi dua, separohnya menjadi hak juragan pemilik perahu dan separoh lagi menjadi hak ABK.

Juragan laut adalah pemilik perahu yang ikut melaut, selain membiayai perbekalan melaut, biasanya juga berperan sebagai nahkoda kapal (juru mudi). Jika demikian selain memperoleh separoh dari perolehan ikan dia juga menerima bagian sebagai juru mudi.

ABK adalah pekerja di perahu yang ikut melaut dan mengerjakan semua pekerjaan teknis di laut, mulai dari menyiapkan peralatan melaut yaitu menata payang (jaring), mengangkut perbekalan ke perahu, melaut sampai mengangkut, ikan hasil tangkapan ke darat. Pada perahu sekoci, mereka sekaligus memasak makanan mereka di laut.

Pengambek (pemodal perbekalan melaut) adalah orang yang membiayai perbekalan melaut terdiri dari solar dan bahan makanan dengan imbalan $10 \%$ hasil tangkapan ikan, mereka umumnya dibutuhkan karena pemilik perahu keterbatasan modal.

Blantik (makelar) adalah orang yang melakukan pembelian ikan dari nelayan setelah melaut dan menjualnya kembali ke pedagang yang lebih besar atau ke TPI, mereka dibutuhkan karena biasanya nelayan menginginkan ikannya segera terutama untuk jumlah yang sedikit (jatah ABK).

Pengolah Ikan adalah orang yang melakukan aktivitas pengolahan hasil tangkapan ikan dan memasarkannya. Di daerah penelitian didabatkan berbagai bentuk olahan ikan yaitu pindang, ikan asin, abon ikan dan sedikit petis. Responden penelitian terdiri dari pengolah abon dan pindang, karena pada saat penelitian sedang musim hujan sehingga tidak ada (sangat sedikit) proses pengeringan ikan.

\section{Deskripsi Identitas Responden Umur Responden}

Umur terkait dengan kemampuan tenaga fisik dan pengalaman kerja seseorang. Nelayan banyak memerlukan aktivitas fisik sehingga dibutuhkan kekuatan fisik. Kisaran umur responden berdasarkan kategori nelayan adalah sebagai berikut.

Tabel 1. Menunjukkan kisaran umur nelayan pada berbagai kategori. Data menunjukkan usia juragan laut terbanyak pada kisaran 30-40 tahun. Sedangkan juragan darat paling banyak adalah pada kisaran usia 40-60 tahun.

Tabel 1. Kisaran umur responden berdasarkan kategori nelayan

\begin{tabular}{llccc}
\hline No & Kriteria & Jumlah responden & Kisaran Umur & \% \\
\hline 1 & Juragan darat & 8 & $<40$ th & 12,50 \\
\cline { 3 - 5 } & & & $40-60$ th & 87,50 \\
\hline 2 & Juragan laut & 10 & $<30$ th & 30,00 \\
\hline
\end{tabular}




\begin{tabular}{llccc}
\hline & & $30-40$ th & 70,00 \\
\hline 3 & ABK & 16 & $<30$ th & 62,50 \\
\cline { 3 - 5 } & & $80-40$ th & 37,50 \\
\hline 4 & Blantik & & $30-40$ th & 60,00 \\
\hline & & 3 & $30-50$ th & 40,00 \\
\hline 5 & Pengambek & 5 & $40-50$ th & 100,00 \\
\hline 6 & Pengolah & & 300,00 \\
\hline
\end{tabular}

Tabel 1. Menunjukkan kisaran umur nelayan pada berbagai kategori. Data menunjukkan usia juragan laut terbanyak pada kisaran 30-40 tahun. Sedangkan juragan darat paling banyak adalah pada kisaran usia 40-60 tahun.

Pada kategori pengambek, blantik dan pengolah ikan menunjukkan sebaran umur dengan kecenderungan tertentu. Disini terlihat usia responden yang berprofesi sebagai blantik sebagian besar berusia 30-40 tahun. Kategori pengambek responden berkisar pada usia 30-40 tahun. Pada kategori pengolah semuanya berusia 40-50 tahun. Data tersebut menunjukkan bahwa sebagian besar responden adalah mereka yang masih dalam usia produktif.

\section{Deskripsi Keluarga Responden}

Rata-rata keluarga yang ditemui sebagai responden baik dari stara juragan, ABK atau kategori lain mempunyai deskripsi keluarga yang tidak berbeda. Mereka mempunyai anak-anka maksimal 4 orang. Tingkat pendidikan orang tuanya mayoritas hanya lulus SD. Sekarang karena di dusun setempat sudah ada SMP maka para orangtua sudah mempunyai kesadaran untuk menyekolahkan anaknya minimal sampai SMP (baik juragan atau ABK). Sebagian dari anak-anak mereka sudah menikmati jenjang SMP bahkan ada yang melanjutkan ke SMA meskipun harus ke luar desa, ke Turen atau Malang.

Tingkatan sosial ekonoi keluarga nelayan tercermin pada kondisi rumah yang ditempati. Para juragan terkelompok pada perkampungan/perumahan yang mereka sebut perumahan elit (untuk ukuran setempat), sedangkan kelompok ABK tinggal pada perkampunagn yang letaknya lebih jauh dari pantai.

\section{Hasil Analisis Gender}

Kerangka analisis gender metode Harvard terdiri dari tiga aspek yaitu: profil aktifitas, profil akses dan kontrol, serta profil manfaat dan dampak. Semua aspek yang dibahas dipisahkan antara kategori nelayan yaitu juragan darat, juragan laut, ABK, Blantik, Pengambek, dan Pengolah.

\section{Analisis Aktivitas Pekerjaan Produktif}

Pekerjaan produktif nelayan dari mempersiapkan menangkap ikan hingga aktivitas pasca tangkap ikan. Profil aktivitas tersebut berturut turut dibahas pada bagian berikut.

Tabel 2 Aktivitas Pekerjaan Produktif Juragan Darat

\begin{tabular}{lcccc}
\hline \multicolumn{1}{c}{ Aktivitas } & $\begin{array}{c}\text { Nelayan } \\
\text { Perempuan }\end{array}$ & $\begin{array}{c}\text { Nelayan Laki } \\
\text { laki }\end{array}$ & $\begin{array}{c}\text { Pekerja } \\
\text { Perempuan }\end{array}$ & $\begin{array}{c}\text { Pekerja Laki - } \\
\text { Laki }\end{array}$ \\
\hline & $\%$ & $\%$ & $\%$ & $\%$ \\
\hline $\begin{array}{l}\text { Pencucian perahu } \\
\text { Persiapan peralatan }\end{array}$ & - & - & - & 100,0 \\
$\begin{array}{l}\text { tangkap } \\
\text { Persiapan bekal BBM }\end{array}$ & - & 62,5 & - & 100,0 \\
\hline Persiapan bekal makanan & 100,0 & 100,0 & - & 37,5 \\
\hline Melaut & - & - & 100,0 & - \\
\hline Pendaratan ikan & - & - & - & 100,0 \\
\hline Penyortiran & - & - & - & 100,0 \\
\hline Penimbangan & - & - & - & 100,0 \\
\hline Pelelangan & 25,0 & - & - & 100,0 \\
\hline
\end{tabular}

Keterangan : Ada 8 juragan darat

Tabel 2 menunjukkan kegiatan produktif Juragan Darat yang meliputi aktivitas pencucian perahu, persiapan peralatan tangkap, melaut, pendaratan ikan, penyortiran, penimbangan, dan pelelangan. 
Partisipasi juragan laki-laki Nampak pada aktivitas persiapan peralatan, perbekalan BBM dan pelelangan. Peran juragan nelayan perempuan adalah pada aktivitas persiapan bekal makanan dan pelelangan. Pada persiapan bekal makanan nelayan perempuan melibatkan pekerja perempuan skitar 5 orang, biasanya dari istri ABK. Bantuan pekerja perempuan untuk memasak ini diperlukan karena untuk satu kapal yang dibutuhkan bekal makanan matang untuk sekitar 15 orang selama 2 hari melaut. Jika juragan memberangkatkan 2 perahu paying berarti harus menyiapkan makanan sekitar 100 porsi. Pada perahu sekoci persiapan bekal makanan tidak terlalu repot karena mereka membawa bekal bahan mentah untuk dimasak dilaut.

Ada hal yang menarik peran juragan perempuan terlibat dalam pelelangan ikan. Mereka menunggu saat perahu mendarat dan mengontrol saat pelelangan ikan. Alasan partisipasi perempuan pada pelelangan ikan karena perempuan dianggap berbakat dalam tawar menawar untuk transaksi penjualan.

Tabel 3 Aktivitas Pekerjaan Produktif Juragan Laut

\begin{tabular}{lcccc}
\hline \multicolumn{1}{c}{ Aktivitas } & $\begin{array}{c}\text { Nelayan } \\
\text { Perempuan }\end{array}$ & $\begin{array}{c}\text { Nelayan Laki } \\
\text { laki }\end{array}$ & $\begin{array}{c}\text { Pekerja } \\
\text { Perempuan }\end{array}$ & $\begin{array}{c}\text { Pekerja Laki - } \\
\text { Laki }\end{array}$ \\
\hline & $\%$ & $\%$ & $\%$ & \% \\
\hline Pencucian perahu & - & 10,0 & - & 90,0 \\
\hline $\begin{array}{l}\text { Persiapan peralatan } \\
\text { tangkap }\end{array}$ & - & 80,0 & - & 40,0 \\
\hline Persiapan bekal BBM & - & 100,0 & - & - \\
\hline Persiapan bekal makanan & 100,0 & - & 60,0 & - \\
\hline Melaut & - & - & - & 100,0 \\
\hline Pendaratan ikan & - & - & - & 80,0 \\
\hline Penyortiran & - & 20,0 & - & 80,0 \\
\hline Penimbangan & - & 20,0 & - & 30,0 \\
\hline Pelelangan & 80,0 & 20,0 & & \\
\hline
\end{tabular}

Keterangan : Ada 10 juragan laut

Tabel 3 menunjukkan kegiatan produktif Juragan laut juga dominan partisipasi laki-laki. Bedanya dengan aktvitas juragan darat adalah disini pemilik perahu ikut melaut. Pada persiapan bekal makanan tidak semua juragn laut merekrut pekerja, hanya $60 \%$ yang merekrut pekerja perempuan. Hal ini dikarenakan sebagian dari keluarga juragan laut mempunyai perahu sekoci yang membawa bekal bahan mentah.

Pada kategori ini peran nelayan perempuan dalam pelelangan ikan cukup besar mencapai 80\%. Pembagian pekerjaan antara nelayan laki-laki dan perempuan mempunyai alas an bahwa setelah suami lelah melaut maka istri membantu saat pelelangan. Disamping itu juga ada alasan karena perempuan lebih telaten dalam tawar menawar.

Tabel 4 Aktivitas Pekerjaan Produktif ABK

\begin{tabular}{lcccc}
\hline \multicolumn{1}{c}{ Aktivitas } & Istri ABK & ABK Laki - laki & $\begin{array}{c}\text { Pekerja } \\
\text { Perempuan }\end{array}$ & $\begin{array}{c}\text { Pekerja Laki - } \\
\text { Laki }\end{array}$ \\
\hline & $\%$ & $\%$ & $\%$ & $\%$ \\
\hline Pencucian perahu & - & 100,0 & - & - \\
\hline $\begin{array}{l}\text { Persiapan peralatan } \\
\text { tangkap }\end{array}$ & - & 100,0 & - & - \\
\hline Persiapan bekal BBM & - & 100,0 & - & - \\
\hline Persiapan bekal makanan & 37,5 & - & - & - \\
\hline Melaut & - & 100,0 & - & - \\
\hline Pendaratan ikan & - & 100,0 & - & - \\
\hline Penyortiran & - & 100,0 & - & - \\
\hline Penimbangan & - & 100,0 & - & - \\
\hline Pelelangan & - & 25,0 & - & \\
\hline
\end{tabular}




\section{Keterangan : Ada 16 ABK}

Tabel 4 menunjukkan bahwa ABK mengerjakan semua aktivitas produktif selama melaut, bahkan diantaranya ada yang terlibat dalam pelelangan. ABK yang terlibat dalam pelelangan ikan ini karena membantu juragan perempuan saat melelang ikan, yaitu ABK dari juragan darat yang suami tidak ikut melelang. Partisipasi istri juga ada pada persiapan bekal makanan karena direkrut oleh juragan perahu payang.

Tabel 5 Aktivitas Pekerjaan Produktif Blantik

\begin{tabular}{lcccc}
\hline Aktivitas & $\begin{array}{c}\text { Blantik } \\
\text { Perempuan }\end{array}$ & $\begin{array}{c}\text { Blantik } \\
\text { Laki - laki }\end{array}$ & $\begin{array}{c}\text { Pekerja } \\
\text { Perempuan }\end{array}$ & $\begin{array}{c}\text { Pekerja Laki - } \\
\text { Laki }\end{array}$ \\
\hline & $\mathbf{\%}$ & $\mathbf{\%}$ & $\boldsymbol{\%}$ & $\boldsymbol{\%}$ \\
\hline Menunggu perahu datang & 75,0 & 25,0 & - & - \\
\hline Tawar menawar & 75,0 & 25,0 & - & - \\
\hline Menentukan ikan dilelang & 75,0 & 25,0 & - & - \\
\hline Pelelangan & 50,0 & 25,0 & - & - \\
\hline Penimbangan & 50,0 & 25,0 & - & - \\
\hline
\end{tabular}

Keterangan : Ada 6 blantik perempuan, 2 blantik laki - laki

Blantik (makelar) adalah orang yang melakukan pembelian ikan dari nelayan setelah melaut dan menjualnya kembali ke pedagang yang lebih besar atau ke TPI. Aktivitas mereka bias seharian berada di TPI menunggu perahu yang dating untuk membeli hasil tangkapannya. Bedanya dengan juragan perempuan pemilik perahu adalah mereka hanya menunggu perahu miliknya. Blantik ini setiap saat menunggu perahu siapa saja yang datang mendarat.

Diantara 8 responden balantik, 6 diantaranya adalah perempuan. Aktivitas mereka banyak terkait dengan tawar menawar dalam transaksi penjualan ikan. Banyaknya perempuan dalam profesi blantik ini makin memperkuat anggapan bahwa perempuan lebih berbakat dalam transaksi jual beli.

Tabel 6 Aktivitas Pekerjaan Produktif Pengambek

\begin{tabular}{lcccc}
\hline \multicolumn{1}{c}{ Aktivitas } & $\begin{array}{c}\text { Pengambek } \\
\text { Perempuan }\end{array}$ & $\begin{array}{c}\text { Pengambek } \\
\text { Laki - laki }\end{array}$ & $\begin{array}{c}\text { Pekerja } \\
\text { Perempuan }\end{array}$ & $\begin{array}{c}\text { Pekerja Laki - } \\
\text { Laki }\end{array}$ \\
\hline $\begin{array}{l}\text { Menghitung kebutuhan } \\
\text { bekal }\end{array}$ & $\mathbf{\%}$ & $\mathbf{\%}$ & $\mathbf{\%}$ & \% \\
\hline Persiapan bekal BBM & 33,3 & 66,6 & - & - \\
\hline Persiapan bekal makanan & 33,3 & 63,6 & - & 33,3 \\
\hline Menunggu perahu datang & 33,3 & 66,6 & 33,3 & - \\
\hline Menunggu pelelangan & 33,3 & 66,6 & - & - \\
\hline Menghitung bagian ikan & 33,3 & 66,6 & - & - \\
\hline Penjualan ikan & 33,3 & 66,6 & & - \\
\hline
\end{tabular}

Keterangan : Ada 1 Pengambek perempuan, 2 Pengambek laki-laki

Sebagian pengambek dibantu pekerja dalam persiapan perbekalan. Ada juga pengambek yang tidak mengurus perbekalan sendiri tetapi menyerahkan uang kebutuhannya pada pemilik perahu. Keberadaan pengambek memang dibutuhkan terutama jika pemilik perahu tidak mempunyai atau kekurangan modal untuk melaut, karena terkadang harus membiayai sampai 7 perahu.

Modal yang dibutuhkan untuk membiayai kebutuhan melaut biasa mencapai $\mathrm{Rp} 1.500 .000$,- Jika juragan mempunyai 4 perahu mereka membutuhkan sekitar 6 jutaan untuk sekali melaut. Kesepakatan pemilik perahu dengan pengambek adalah bagian pengambek sebesar $10 \%$ dari nilai total perolehan ikan. Jika perolehan ikan mencapai nilai Rp 3.000.000 maka dia menerima Rp 300.000 dan modalnya yang sekitar 1-1,5 jutaan juga kembali. Perolehan ini tentu dianggap cukup besar (20\% dari modal) untuk waktu 2 
hari sampai satu minggu. Namun jika perahu tidak memperoleh ikan maka pengambek juga tidak mendapat bagian keuntungan, sedangkan modal yang diberikan sebagai hutang.

Kesepakatan hubungan tersebut menyebabkan aktivitas pengambek banyak dilakukan di Tempat Pelelangan Ikan. Mereka harus menunggu saat kedatangan perahu untuk mengetahui secara pasti perolehan ikan dari perahu yang diberi modal agar bagian keuntungannya tidak berkurang. Sistem kerja seperti ini juga memungkinkan perempuan ikut partisipasi menjadi pengambek. Responden pengambek perempuan tidak banyak jumlahnya, selain karena keterbatasan modal juga alokasi waktunya masih untuk pekerjaan domestik.

Tabel 7 Aktivitas Pekerjaan Produktif Pengolah

\begin{tabular}{lcccc}
\hline \multicolumn{1}{c}{ Aktivitas } & $\begin{array}{c}\text { Pengolah } \\
\text { Perempuan }\end{array}$ & $\begin{array}{c}\text { Pengolah } \\
\text { Laki - laki }\end{array}$ & $\begin{array}{c}\text { Pekerja } \\
\text { Perempuan }\end{array}$ & $\begin{array}{c}\text { Pekerja Laki - } \\
\text { Laki }\end{array}$ \\
\hline & $\mathbf{\%}$ & $\boldsymbol{\%}$ & $\boldsymbol{\%}$ & \% \\
\hline Pembelian ikan & 80,0 & - & - & 20,0 \\
\hline Persiapan alat & 100,0 & - & - & - \\
\hline Persiapan bahan & 100,0 & - & 100,0 & - \\
\hline Pengolahan & 100,0 & - & 60,0 & 40,0 \\
\hline Pengawetan ikan & 100,0 & - & 60,0 & 40,0 \\
\hline Pengemasan olahan & 100,0 & - & 100,0 & - \\
\hline Penjualan hasil olahan & 100,0 & - & 60,0 & 40,0 \\
\hline
\end{tabular}

Keterangan : Ada 5 pengolah semua perempuan

Responden penelitian semuanya perempuan terdiri dari pengolah abon dan pindang, meskipun mereka juga dibantu tenaga laki-laki untuk tenaga fisik yang berat. Untuk pengolah abon ikan masih sedikit jumlhanya karena teknisnya masih dianggap sulit dan menggunakan alat vacum drying yang relative mahal. Alat yang dimiliki merupakan bantuan Dinas Perikan Propinsi untuk Kelompok Wanita Nelayan (KWN).

Tabel 7 menunjukkan aktivitas pengolah ikan didominasi perempuan baik pengelola maupun pekerja. Pembagian pekerja menunjukkan bahwa pembagian kerja masyarakat nelayan masih dipengaruhi oleh pandangan tradisional bahwa kegiatan yang berhubungan denagn masak-memasak adalah kegiatan yang melekat pada perempuan.

\section{Analisis Aktivitas Pekerjaan Reproduktif}

Profil pekerjaan reproduktif juga dipisahkan antara masing-masing kategori nelayan agar dapat memberikan gambaran yang jelas karena karakteristik pekerjaan mereka memang berbeda.

Tabel 8 Aktivitas Pekerjaan Reproduktif Keluarga Juragan Darat

\begin{tabular}{lcccc}
\hline \multicolumn{1}{c}{ Aktivitas } & $\begin{array}{c}\text { Nelayan } \\
\text { Perempuan }\end{array}$ & $\begin{array}{c}\text { Nelayan Laki - } \\
\text { laki }\end{array}$ & $\begin{array}{c}\text { Pekerja } \\
\text { Perempuan }\end{array}$ & $\begin{array}{c}\text { Pekerja Laki - } \\
\text { Laki }\end{array}$ \\
\hline Mengasuh anak & $\mathbf{\%}$ & $\mathbf{\%}$ & $\%$ & \% \\
\hline Memasak & 100,0 & 25,0 & 25,0 & - \\
\hline Mencuci pakaian & 100,0 & 12,5 & 75,0 & - \\
\hline Membersihkan rumah & 100,0 & - & 75,0 & 25,0 \\
\hline
\end{tabular}

Keterangan : Ada 8 juragan darat semua laki-laki

Aktivitas pekerjaan domestik pada keluarga juragan darat sangat dominan dilakukan nelayan perempuan dan anak perempuan mereka. Jika ditanyakan lebih jauh ternyata sebagian juragan laki-laki ada yang banyak beraktivitas di kelompok nelayan sebagai pengurus atau sekedar mengecek ke TPI karena sudah terlalu tua untuk melaut. Meskipun mereka tidak sibuk pendapatan ikan sudah memadai, sedangkan pekerjaan domestic dianggap sebagai tugas perempuan. 
Tabel 9 Aktivitas Pekerjaan Reproduktif Keluarga Juragan Laut

\begin{tabular}{lcccc}
\hline Aktivitas & $\begin{array}{c}\text { Nelayan } \\
\text { Perempuan }\end{array}$ & $\begin{array}{c}\text { Nelayan Laki - } \\
\text { laki }\end{array}$ & $\begin{array}{c}\text { Pekerja } \\
\text { Perempuan }\end{array}$ & $\begin{array}{c}\text { Pekerja Laki - } \\
\text { Laki }\end{array}$ \\
\hline Mengasuh anak & $\mathbf{\%}$ & $\mathbf{\%}$ & $\mathbf{\%}$ & $\boldsymbol{\%}$ \\
\hline Memasak & 100,0 & 25,0 & 25,0 & - \\
\hline Mencuci pakaian & 100,0 & 12,5 & 75,0 & - \\
\hline Membersihkan rumah & 100,0 & - & 75,0 & 25,0 \\
\hline
\end{tabular}

Keterangan : Ada 10 juragan laut semua laki-laki

Aktivitas pekerjaan domestik pada keluarga juragan laut sangat dominan dilakukan nelayan perempuan dan anak perempuan mereka. Pada keluarga kategori ini nelayan laki-laki ikut melaut. Disini dari pembagian kerja memang relative adil dibandingkan dengan keluarga juragan darat. Permasalahannya adalah masih lekatnya anggapan pekerjaan domestic merupakan tugas perempuan.

Tabel 10 Aktivitas Pekerjaan Reproduktif Keluarga ABK

\begin{tabular}{lcccc}
\hline Aktivitas & $\begin{array}{c}\text { Nelayan } \\
\text { Perempuan }\end{array}$ & $\begin{array}{c}\text { Nelayan Laki - } \\
\text { laki }\end{array}$ & $\begin{array}{c}\text { Pekerja } \\
\text { Perempuan }\end{array}$ & $\begin{array}{c}\text { Pekerja Laki - } \\
\text { Laki }\end{array}$ \\
\hline & $\mathbf{9}$ & $\mathbf{\%}$ & $\mathbf{\%}$ & $\boldsymbol{\%}$ \\
\hline Mengasuh anak & 75,0 & - & 37,5 & 6,25 \\
\hline Memasak & 75,0 & - & 37,5 & - \\
\hline Mencuci pakaian & 75,0 & - & 18,75 & 6,25 \\
\hline Membersihkan rumah & 75,0 & - & - & - \\
\hline
\end{tabular}

\section{Keterangan : Ada 16 ABK semua laki-laki}

Pada keluarga ABK pekerjaan domestik sangat dominan dilakukan nelayan perempuan dan anak perempuan atau keluarga lain (nenek). Sebagian istri ABK menjadi TKW di luar negri sehingga pekerjaan domestik rumah dikerjakan anggota perempuan lain. Disini terlihat bantuan ank perempuan Nampak lebih banyak dibandingakan keluarga juragan darat maupun juragan laut. Hal ini disebabkan mereka mempunyai tingkat kesejahteraan terendah diantara kategori nelayan.

Tabel 11 Aktivitas Pekerjaan Reproduktif Keluarga Blantik

\begin{tabular}{lcccc}
\hline Aktivitas & $\begin{array}{c}\text { Blantik } \\
\text { Perempuan }\end{array}$ & $\begin{array}{c}\text { Blantik Laki - } \\
\text { laki }\end{array}$ & $\begin{array}{c}\text { Pekerja } \\
\text { Perempuan }\end{array}$ & $\begin{array}{c}\text { Pekerja Laki - } \\
\text { Laki }\end{array}$ \\
\hline & $\boldsymbol{\%}$ & $\boldsymbol{\%}$ & $\boldsymbol{\%}$ & \% \\
\hline Mengasuh anak & 100,0 & - & - & - \\
\hline Memasak & 75,0 & - & 25,0 & - \\
\hline Mencuci pakaian & 75,0 & - & 37,5 & - \\
\hline Membersihkan rumah & 75,0 & - & 25,0 & - \\
\hline
\end{tabular}

Keterangan : Ada 6 blantik perempuan, 2 blantik laki-laki

Pada keluarga blantik pekerjaan domestik juga tetap dikerjakan perempuan meskipun mereka sudah banyak menghabiskan waktu di TPI. Sebagian blantik perempuan juga ada yang sangat sibuk di TPI sekitar 25\% blantik perempuan yang jarang memasak dan pekerjaan domestik lainnya dibantu anak perempuan da nada satu suami responden yang mau memasak di rumah. Pada blantik laki-laki sama sekali mereka tidak pernah melakukan pekerjaan domestik. 
Tabel 12 Aktivitas Pekerjaan Reproduktif Keluarga Pengambek

\begin{tabular}{lcccc}
\hline Aktivitas & $\begin{array}{c}\text { Pengambek } \\
\text { Perempuan }\end{array}$ & $\begin{array}{c}\text { Pengambek Laki } \\
\text { - laki }\end{array}$ & $\begin{array}{c}\text { Pekerja } \\
\text { Perempuan }\end{array}$ & $\begin{array}{c}\text { Pekerja Laki - } \\
\text { Laki }\end{array}$ \\
\hline Mengasuh anak & $\mathbf{\%}$ & $\mathbf{\%}$ & $\mathbf{\%}$ & $\mathbf{\%}$ \\
\hline Memasak & 66,6 & - & 33,3 & - \\
\hline Mencuci pakaian & 66,6 & 33,0 & 66,6 & - \\
\hline Membersihkan rumah & 100,0 & 33,0 & - & - \\
\hline
\end{tabular}

Keterangan : Ada 1 pengambek perempuan, 2 pengambek laki-laki

Pada keluarga pengambek pekerjaan domestik juga tetap dikerjakan perempuan meskipun ada pengambek laki-laki yang mau mengerjakan pekerjaan domistik. Responden pengambek perempuan tidak banyak demikian juga perahu yang dibiayai, selain karena keterbatasan modal juga alokasi waktunya masih untuk pekerjaan domestik.

Tabel 13 Aktivitas Pekerjaan Reproduktif Keluarga Pengolah

\begin{tabular}{lcccc}
\hline Aktivitas & $\begin{array}{c}\text { Nelayan } \\
\text { Perempuan }\end{array}$ & $\begin{array}{c}\text { Nelayan Laki - } \\
\text { laki }\end{array}$ & $\begin{array}{c}\text { Pekerja } \\
\text { Perempuan }\end{array}$ & $\begin{array}{c}\text { Pekerja Laki - } \\
\text { Laki }\end{array}$ \\
\hline & $\mathbf{\%}$ & $\boldsymbol{\%}$ & $\boldsymbol{\%}$ & $\%$ \\
\hline Mengasuh anak & 100,0 & - & - & - \\
\hline Memasak & 100,0 & - & 40,0 & - \\
\hline Mencuci pakaian & 100,0 & - & 40,0 & - \\
\hline Membersihkan rumah & 100,0 & - & - & 20,0 \\
\hline
\end{tabular}

Keterangan : Ada 1 pengambek perempuan, 2 pengambek laki-laki

Pada keluarga pengolah ikan aktivitas domestik juga tetap dikerjakan perempuan meskipun pada pada saat pengolahan ikan mereka sangat sibuk. Misalnya saat pekerjaan merebus pindang atau saat penegringan abon masih bias diambil dengan pekerjaan masak untuk konsumsi sehari-hari. Urusan domestic juga banyak dibantu anka perempuan. Lagi-lagi urusan pekerjaan domestic masih melekat pada perempuan.

\section{Analisis Akses Pada Sumberdaya}

Akses pada sumberdaya sangat penting bagi seseorang untuk dapat memanfaatkannya dan melakukan aktivitas yang produktif.

Tabel 14 Kesempatan Akses Sumberdaya Bagi Juragan Darat

\begin{tabular}{|c|c|c|c|c|c|}
\hline Sumberdaya & $\begin{array}{c}\text { Nelayan } \\
\text { Perempuan }\end{array}$ & $\begin{array}{c}\text { Nelayan Laki } \\
\text { - laki }\end{array}$ & $\begin{array}{c}\text { Nelayan } \\
\text { L\&P }\end{array}$ & $\begin{array}{c}\text { Pekerja } \\
\text { Perempuan }\end{array}$ & $\begin{array}{l}\text { Pekerja Laki- } \\
\text { laki }\end{array}$ \\
\hline & $\%$ & $\%$ & $\%$ & $\%$ & \\
\hline $\begin{array}{l}\text { Peralatan tangkap } \\
\text { ikan }\end{array}$ & - & 100,0 & - & - & 100,0 \\
\hline $\begin{array}{l}\text { Peralatan } \\
\text { pascatangkap }\end{array}$ & 12,5 & 87,5 & - & - & 100,0 \\
\hline $\begin{array}{l}\text { Tempat penjualan } \\
\text { (TPI) }\end{array}$ & 50,0 & 87,5 & - & - & - \\
\hline Kelompok nelayan & - & 100,0 & - & - & 20,0 \\
\hline Kredit & 12,5 & - & 87,5 & - & - \\
\hline
\end{tabular}

Keterangan : Ada 8 juragan darat semua laki-laki 
Nelayan laki-laki dapat mengakses setiap sumberdaya terkait dengan aktivitas mereka. Ada juga diantara mereka tidak mengakses sumberdaya karena mereka mempercayakan sepenuhnya pada pekerja terutama orang kepercayaan. Dalam hal akses kredit nelayan suami istri dapat mengaksesnya bersama-sama. Yang menarik ada nelayan juragan yang menyerahkan akses kredit sepenuhnya pada istri.

Tabel 15 Kesempatan Akses Sumberdaya Bagi Juragan Laut

\begin{tabular}{lccccc}
\hline \multicolumn{1}{c}{ Sumberdaya } & $\begin{array}{c}\text { Nelayan } \\
\text { Perempuan }\end{array}$ & $\begin{array}{c}\text { Nelayan Laki } \\
- \text { laki }\end{array}$ & $\begin{array}{c}\text { Nelayan } \\
\text { L\&P }\end{array}$ & $\begin{array}{c}\text { Pekerja } \\
\text { Perempuan }\end{array}$ & $\begin{array}{c}\text { Pekerja Laki- } \\
\text { laki }\end{array}$ \\
\hline $\begin{array}{l}\text { Peralatan tangkap } \\
\text { ikan }\end{array}$ & \% & \% & \% & $\%$ & \\
\hline $\begin{array}{l}\text { Peralatan } \\
\text { pascatangkap }\end{array}$ & - & 100,0 & - & - & 100,0 \\
$\begin{array}{l}\text { Tempat penjualan } \\
\text { (TPI) }\end{array}$ & - & 100,0 & - & - & 100,0 \\
\hline Kelompok nelayan & - & 100,0 & - & - & 30,0 \\
\hline Kredit & 8,0 & 100,0 & - & - & - \\
\hline
\end{tabular}

Keterangan : Ada 10 juragan laut semua laki-laki

Pada juragan laut nelayan laki-laki dapat mengakses setiap sumberdaya terkait dengan aktivitas mereka. Apalagi karena juragan laut ikut melaut maka semua sumberdaya diakses. Dalam sumberdaya tertentu seperti menjadi kelompok nelayan tetap dapat dilakukan oleh nelayan yang bersangkutan. Dalam hal akses kredit nelayan suami istri dapat mengaksesnya bersama-sama. Bahkan ada nelayan juragan laut yang menyerahkan akses kredit sepenuhnya pada istri.

Tabel 16 Kesempatan Akses Sumberdaya Bagi ABK

\begin{tabular}{lccccc}
\hline \multicolumn{1}{c}{ Sumberdaya } & Istri ABK & $\begin{array}{c}\text { ABK } \\
\text { Laki - laki }\end{array}$ & $\begin{array}{c}\text { Pekerja } \\
\text { perempuan }\end{array}$ & ABK \& Istri & $\begin{array}{c}\text { Pekerja Laki- } \\
\text { laki }\end{array}$ \\
\hline & $\%$ & $\%$ & $\%$ & $\%$ & - \\
\hline $\begin{array}{l}\text { Peralatan tangkap } \\
\text { ikan }\end{array}$ & - & 100,0 & - & - & - \\
\hline $\begin{array}{l}\text { Peralatan } \\
\text { pascatangkap }\end{array}$ & - & 100,0 & - & - & - \\
\hline $\begin{array}{l}\text { Tempat penjualan } \\
\text { (TPI) }\end{array}$ & - & 100,0 & - & - & - \\
\hline KUD & 12,5 & 37,5 & - & - & - \\
\hline Kelompok nelayan & - & 100,0 & - & - & - \\
\hline Pinjaman & - & - & - & 100,0 & - \\
\hline
\end{tabular}

Keterangan : Ada 16 ABK semua laki-laki

ABK mempunyai akses pada semua sumberdaya terkait dengan penangkapan ikan. Karena mereka hanya pekerja maka akses pada kelompok dan kredit juga terbatas. Ada akses ke KUD dan boleh mengikuti aktivitas simpan pinjam. Semua ABK berkelompok dalam satu juragan dan boleh mengambil pinjaman uang pada juragan masing-masing. Jadi akses kelompok nelayan adalah kelompok dalam satu juragan dan akses kredit adalah pinjaman pada juragan tersebut. Pinjaman ke juragan tersebut harus sepengetahuan suami istri agar ada tanggung jawab bersama dalam hal pinjaman. 
Tabel 17 Kesempatan Akses Sumberdaya Bagi Blantik

\begin{tabular}{lcccc}
\hline \multicolumn{1}{c}{ Sumberdaya } & $\begin{array}{c}\text { Blantik } \\
\text { Perempuan }\end{array}$ & $\begin{array}{c}\text { Blantik Laki - } \\
\text { laki }\end{array}$ & $\begin{array}{c}\text { Pekerja } \\
\text { perempuan }\end{array}$ & $\begin{array}{c}\text { Pekerja Laki- } \\
\text { laki }\end{array}$ \\
\hline $\begin{array}{l}\text { Peralatan tangkap } \\
\text { ikan }\end{array}$ & $\%$ & $\%$ & $\%$ & $\%$ \\
\hline $\begin{array}{l}\text { Peralatan } \\
\text { pascatangkap }\end{array}$ & - & - & - & - \\
\hline $\begin{array}{l}\text { Tempat penjualan } \\
\text { (TPI) }\end{array}$ & 37,5 & 62,5 & - & - \\
\hline Kelompok nelayan & - & - & - & - \\
\hline Pinjaman & 50 & 50 & - & - \\
\hline
\end{tabular}

Keterangan : Ada 6 blantik perempuan dan 2 blantik laki-laki

Sebagaimana terungkap pada Tabel 17 kesempatan akses terhadap sumberdaya bagi blantik di Sendangbiru hanya terfokus pada kegiatan di tempat penjualan ikan dan kredit. Kesempatan akses terhadap kegiatan di tempat penjualan ikan dan kredit. Kesempatan akses terhadap kegiatan di tempat penjualan ikan bagi blantik perempuan hanya 37,5\% dan bagi blantik laki-laki sebesar 62,5\% sedangkan kesempatan untuk mendapatkan untuk mendapatkan kredit bagi blantik laki-laki dan perempuan adalah sama besarnya (50\%).

Blantik perempuan dapat mengambil alih posisi di arena pelelangan adalah lebih dikarenakan oleh ketiadaan blantik laki-lakidi tempat pelelangan (digantikan istrinya). Kondisi lainnya yang memberikan kesempatan akses lebih besar kepada blantik perempuan adalah apabila blantik laki-laki tidak tertarik pada jenis ikan yang dilelang.

Tabel 18 Kesempatan Akses Sumberdaya Bagi Pengambek

\begin{tabular}{lcccc}
\hline Sumberdaya & $\begin{array}{c}\text { Pengambek } \\
\text { Perempuan }\end{array}$ & $\begin{array}{c}\text { Pengambek } \\
\text { laki - laki }\end{array}$ & $\begin{array}{c}\text { Pekerja } \\
\text { perempuan }\end{array}$ & $\begin{array}{c}\text { Pekerja Laki- } \\
\text { laki }\end{array}$ \\
\hline & $\boldsymbol{\%}$ & $\mathbf{\%}$ & $\boldsymbol{\%}$ & $\boldsymbol{\%}$ \\
\hline Pemilik perahu & 33,3 & 66,6 & - & - \\
\hline Perbekalan BBM & - & 66,6 & - & 33,6 \\
\hline Perbekalan makanan & 33,3 & 33,3 & 33,3 & - \\
\hline TPI & 33,3 & 66,6 & - & - \\
\hline Petugas lelang & - & - & - & - \\
\hline
\end{tabular}

Keterangan : Ada 1 Pengambek perempuan dan 2 pengambek laki-laki

Para pengambek memiliki akses yang cukup luas terhadap para pemilik perahu, namun kesempatan akses pengambek laki-laki $(66,7 \%)$ daripada penagmbek perempuan (33,3\%). Pengambek lakilaki mempunyai akses dominan 66,7\% terhadap perbekalan BBM. Sedangkan pengambek laki-laki dan perempuan mempunyai akses yang sama terhadap perbekalan makanan nelayan yang mau melaut (33,3\%). Pengambek perempuan hanya memiliki akses terhadap TPI 33,3\% dan laki-laki 66,7\%. Sementara akses yang dimiliki pekerja laki-laki terhadap perbekalan BBM adalah dalam posisi mengangkut dan menurunkan peralatan perbekalan BBM ked an dari atas kapal. Dengan demikian kesempatan akses sumberdaya bagi pengambek laki-laki lebih besardibanding pengambek perempuan. 
Tabel 19 Kesempatan Akses Sumberdaya Bagi Pengolah

\begin{tabular}{lcccc}
\hline Sumberdaya & $\begin{array}{c}\text { Pengambek } \\
\text { Perempuan }\end{array}$ & $\begin{array}{c}\text { Pengambek } \\
\text { laki - laki }\end{array}$ & $\begin{array}{c}\text { Pekerja } \\
\text { perempuan }\end{array}$ & $\begin{array}{c}\text { Pekerja Laki- } \\
\text { laki }\end{array}$ \\
\hline TPI & $\%$ & $\%$ & $\%$ & $\%$ \\
\hline Peralatan produksi & 80,0 & - & - & 20,0 \\
\hline Bahan olahan & 100,0 & - & - & - \\
\hline Kelompok wanita N & 100,0 & - & - & - \\
\hline LEPM & 100,0 & - & - & - \\
\hline Pasar & 100,0 & - & 60,0 & 40,0 \\
\hline
\end{tabular}

Keterangan : Ada 5 pengolah semua perempuan

Kesempatan pengolah untuk mengakses sumberdaya TPI lebih banyak dimiliki oleh pengolah perempuan (80\%) sisanya dimiliki oleh pekerja laki-laki untuk mengangkat dan memindahkan ikan-ikan di kerangjang dalam ukuran besar. Dominasi pengolah perempuan (100\%) sangat menonjol dalam akses terhadap peralatan produksi, bahan olahan, kelompok wanita nelayan, LEPM dan pasar. Sedangkan kesempatan akses bekerja perempuan terlihat dominan pada bahan olah dan pasar. Sedangkan pekerja lakilaki memiliki akses pada TPI dan pasar. Dengan demikian akses pengolah perempuan terhadap sumber daya yang ada lebih tinggi daripada pengolah laki-laki.

\section{Analisis Kontrol Terhadap Sumberdaya}

Tabel 20 Pengontrol Sumberdaya Bagi Juragan Darat

\begin{tabular}{|c|c|c|c|c|c|}
\hline Sumberdaya & $\begin{array}{c}\text { Nelayan } \\
\text { Perempuan }\end{array}$ & $\begin{array}{c}\text { Nelayan laki - } \\
\text { laki }\end{array}$ & $\begin{array}{c}\text { Nelayan L \& } \\
\text { P }\end{array}$ & $\begin{array}{c}\text { Pekerja } \\
\text { Perempuan }\end{array}$ & $\begin{array}{c}\text { Pekerja Laki } \\
\text { - laki }\end{array}$ \\
\hline & $\%$ & $\%$ & $\%$ & $\%$ & $\%$ \\
\hline Peralatan tangkap ikan & - & 100,0 & - & - & 100,0 \\
\hline Peralatan pascatangkap & 12,5 & 87,5 & - & - & 100,0 \\
\hline Tempat penjualan (TPI) & 50,0 & 87,5 & - & - & - \\
\hline Kelompok nelayan & - & 100,0 & - & - & - \\
\hline Kredit & 12,5 & - & 87,5 & - & - \\
\hline
\end{tabular}

Keterangan : Ada 8 juragan darat semua laki - laki

Kontrol terhadap peralatan tangkap didominasi oleh nelayan laki-laki dan pekerja laki-laki (100\%). Sedangkan untuk peralatan pasaca tangkap nelayan perempuan yang melakukan kontrpl sebanyak 12,5\% dan laki-laki 87,5\%. Dalam hal ini kontrol dari nelayan perempuan dan laki-laki masing-masing sebesar 50\% dan 87,5\%. Sementara itu kendali terhadap kelompok nelayan dilakukan oleh nelayan laki-laki (100\%). Adapun kontrol terhadap kredit dilakukan oleh nelayan perempuan (12,5\%) dan nelayan laki-laki $(8,5 \%)$. Secara umum pengontrol sumberdaya juragan darat terletak pada nelayan laki-laki.

Tabel 21 Pengontrol Sumberdaya Bagi Juragan Laut

\begin{tabular}{|c|c|c|c|c|c|}
\hline Sumberdaya & $\begin{array}{c}\text { Nelayan } \\
\text { Perempuan }\end{array}$ & $\begin{array}{c}\text { Nelayan laki - } \\
\text { laki }\end{array}$ & $\begin{array}{c}\text { Nelayan L \& } \\
\text { P }\end{array}$ & $\begin{array}{c}\text { Pekerja } \\
\text { Perempuan }\end{array}$ & $\begin{array}{c}\text { Pekerja Laki } \\
\text { - laki }\end{array}$ \\
\hline & $\%$ & $\%$ & $\%$ & $\%$ & $\%$ \\
\hline Peralatan tangkap ikan & - & 100,0 & - & - & 100,0 \\
\hline Peralatan pascatangkap & - & 100,0 & - & - & 100,0 \\
\hline Tempat penjualan (TPI) & - & 100,0 & - & 30,0 & - \\
\hline Kelompok nelayan & - & 100,0 & - & - & - \\
\hline Kredit & 10,0 & 10,0 & 80,0 & - & - \\
\hline
\end{tabular}


Keterangan : Ada 10 juragan laut semua laki-laki

Tabel 5.21 menunjukkan pengontrol sumberdaya juragan laut yang dilakukan oleh nelayan dan pekerja laki-laki dan perempuan. Kontrol terhadap peralatan tangkap didominasi oleh nelayan laki-laki dan pekerja laki-laki (100\%). Sedangkan untuk peralatan pasaca tangkap nelayan perempuan yang melakukan sebanyak 12,5\% dan laki-laki 87,5\%. Kontrol terhadap tempat penjulan ikan dilakukan oleh nelayan perempuan $(50 \%)$ dan nelayan laki-laki $(87,5 \%)$. Sedangkan kontrol terhadap kredit nelayan perempuan $(12,5 \%)$ dan nelayan laki-laki $(87,5 \%)$. Secara keseluruhan kendali atau control terhadap sumberdaya juragan laut didominasi oleh laki-laki.

Tabel 22 Pengontrol Sumberdaya ABK

\begin{tabular}{lccccc}
\hline \multicolumn{1}{c}{ Sumberdaya } & $\begin{array}{c}\text { Nelayan } \\
\text { Perempuan }\end{array}$ & $\begin{array}{c}\text { Nelayan laki - } \\
\text { laki }\end{array}$ & $\begin{array}{c}\text { Nelayan L \& } \\
\mathbf{P}\end{array}$ & $\begin{array}{c}\text { Pekerja } \\
\text { Perempuan }\end{array}$ & $\begin{array}{c}\text { Pekerja Laki } \\
\text { - laki }\end{array}$ \\
\hline & $\mathbf{\%}$ & $\mathbf{\%}$ & $\mathbf{\%}$ & $\mathbf{\%}$ & \% \\
\hline Peralatan tangkap ikan & - & 100,0 & - & - & 100,0 \\
\hline Peralatan pascatangkap & - & 100,0 & - & - & 100,0 \\
\hline Tempat penjualan (TPI) & - & 100,0 & - & 30,0 & - \\
\hline Kelompok nelayan & - & 100,0 & - & - & - \\
\hline Kredit & 10,0 & 10,0 & 80,0 & - & - \\
\hline
\end{tabular}

Keterangan : Ada 16 ABK semua laki-laki

Tabel 22 menunjukkan ABK laki-laki sangat dominan dalam mengendalikan peralatan tangkap ikan (100\%)disbanding istri ABK. Sedangkan untuk kontrol pada kelompok nelayan tetap didominasi oleh ABK laki-laki $(87,5 \%)$, istri ABK 12,5\%. Sementara itu control terhadap kredit mutlak dilakukan bersamasama.

Tabel 23 Pengontrol Sumberdaya Blantik

\begin{tabular}{lcccc}
\hline \multicolumn{1}{c}{ Sumberdaya } & $\begin{array}{c}\text { Blantik } \\
\text { Perempuan }\end{array}$ & $\begin{array}{c}\text { Blantik } \\
\text { Laki - laki }\end{array}$ & $\begin{array}{c}\text { Pekerja } \\
\text { Perempuan }\end{array}$ & $\begin{array}{c}\text { Pekerja Laki } \\
\text {-laki }\end{array}$ \\
\hline & $\boldsymbol{\%}$ & $\boldsymbol{\%}$ & $\boldsymbol{\%}$ & $\boldsymbol{\%}$ \\
\hline Peralatan tangkap ikan & - & - & - & - \\
\hline Peralatan pascatangkap & - & - & - & - \\
\hline Tempat penjualan (TPI) & 37,5 & 62,5 & - & - \\
\hline Kelompok nelayan & - & - & - & - \\
\hline Kredit & 50 & 50 & - & - \\
\hline
\end{tabular}

Keterangan : Ada 6 blantik perempuan dan 2 blantik laki-laki

Tabel 23 berisi data mengenai pengontrol sumberdaya blantik terhadap TPI dan kredit. Blantik perempuan mampu mengontrol 37,5\% dari seluruh kegiatan di tempat lelang, dan blantik laki-laki 62,5\% sedangkan control terhadap kredit dilakukan secara seimbang antara blantik laki-laki (50\%) dan blantik perempuan (50\%). Berdasarkan data tersebut dapat disimpulkan bahwa meski secara kuantitatif jumlah blantik laki-laki lebih sedikit daripada blantik perempuan, namun dalam kenyataan kontrol terhadap kegiatan di tempat lelang ikan tetap berada di bawah kontrol blantik lai-laki.

Tabel 24. Pengontrol Sumberdaya Pengambek

\begin{tabular}{ccccc}
\hline Sumberdaya & $\begin{array}{c}\text { Pengambek } \\
\text { Perempuan }\end{array}$ & $\begin{array}{c}\text { Pengambek } \\
\text { Laki - laki }\end{array}$ & $\begin{array}{c}\text { Pekerja } \\
\text { Perempuan }\end{array}$ & Pekerja Laki -laki \\
\hline & $\boldsymbol{\%}$ & $\boldsymbol{\%}$ & $\boldsymbol{\%}$ & $\boldsymbol{\%}$ \\
\hline Pemilik perahu & 33,3 & 66,6 & - & - \\
\hline
\end{tabular}




\begin{tabular}{lcccc}
\hline Perbekalan BBM & - & 66,6 & - & 33,3 \\
\hline Perbekalan makanan & 33,3 & 33,3 & 33,3 & - \\
\hline TPI & 33,3 & 66,6 & - & - \\
\hline Petugas lelang & - & - & - & - \\
\hline
\end{tabular}

Keterangan : Ada 1 pengambek perempuan dan 2 pengambek laki-laki

Data Tabel 24 menggambarkan pengontrol sumberdaya pengambek terhadap pemilik perahu, perbekalan BBM, perbekalan makanan, dan tempat pelelangan ikan. Pengontrol sumberdaya pengambek terhadap pemilik perahu dilakukan oleh pengambek perempuan (33,3\%) dan pengambek laki-laki (66,7\%). Kontrol tehadap perbekalan BBM dilkukan oleh pengambek laki-laki dan pekerja laki-laki. Sedangkan control terhadap perbekalan makanan dilakukan oleh pengambek perempuan (33,3\%), pengambek lakilaki $(66,7 \%)$, dan pekerja perempuan sebanyak (33,3\%). Sedangkan pengambek terhadap tempat pelelangan ikan dilakukan oleh pengambek perempuan (33,3\%), dan pengambek laki-laki (66,7\%). Jadi pengontrol sumberdaya pengambek terhadap pemilik perahu, perbekalan BBM, perbekalan makanan dan TPI masih di dominasi oleh pengambek laki-laki.

Tabel 25. Pengontrol Sumberdaya Pengolah

\begin{tabular}{|c|c|c|c|c|}
\hline Sumberdaya & $\begin{array}{c}\text { Pengolah } \\
\text { Perempuan } \\
\%\end{array}$ & $\begin{array}{c}\text { Pengolah } \\
\text { laki-laki } \\
\%\end{array}$ & $\begin{array}{c}\text { Pekerja } \\
\text { Perempuan } \\
\%\end{array}$ & $\begin{array}{c}\text { Pekerja } \\
\text { laki-laki } \\
\%\end{array}$ \\
\hline TPI & 80,0 & - & - & 20,0 \\
\hline Peralatan produksi & 100,0 & - & - & - \\
\hline Bahan olahan & 100,0 & - & 100,0 & - \\
\hline Kelopok wanita N & 100,0 & - & - & - \\
\hline LEPM & 100,0 & - & - & - \\
\hline Pasar & 100,0 & - & 60,0 & 40,0 \\
\hline
\end{tabular}

Keterangan : Ada 5 pengelola semua perempuan

Dalam Tabel 25 mengurai mengenai pengontrol sumberdaya pengolah terhadap kegiatan di tempat pelelangan ikan, peralatan produksi, bahan olahan, kelompok wanita nelayan LEPM dan pasar. Sebagaimana tertera pada Tabel 25, pengolah perempuan sangat mendominasi (100\%) terhadap seluruh aspek sumberdaya yang terkait dengan kegiatan pengolahan ikan laut. Keberadaan pekerja perempuan mengontrol bahan olahan (100\%) dan pasar (60\%) merupakan bagian dari tanggung jawab mereka di bidang pengolahan ikan laut. Sedangkan control pekerja laki-laki di TPI dan di pasar merupakan bagian dari pekerjaan utama mereka sebagai pengangkut ikan. Dengan demikian penontrol sumberdaya pengolah lebih besar dilakukan oleh pengolah perempuan daripada pengolah laki-laki.

\section{Analisis Manfaat dan Dampak Sumberdaya}

Analisis manfaat dan dampak terhadap sumberdaya menguraikan tentang manfaat dan dampak dari aktivitas dan akses nelayan laki-laki dan perempuan bagi keluarga. Manfaat dan dampak yang dirasakan oleh keluarga nelayan khususnya juragan darat dapat dilihat pada Tabel 26. nelayan laki-laki sangat merasakan manfaat dari aktivitasdan akses mereka terhadap sumberdaya nelayan.

Tabel 26. Manfaat dan Dampak Sumberdaya Juragan Darat

\begin{tabular}{cccccc}
\hline \multirow{2}{*}{ Sumberdaya } & $\begin{array}{c}\text { Nelayan } \\
\text { Perempuan } \\
\end{array}$ & $\begin{array}{c}\text { Nelayan } \\
\text { Laki-laki }\end{array}$ & $\begin{array}{c}\text { Anak } \\
\text { Perempuan } \\
\%\end{array}$ & $\begin{array}{c}\text { Anak } \\
\text { Laki-laki } \\
\%\end{array}$ & $\begin{array}{c}\text { Bersama } \\
\%\end{array}$ \\
\hline Peralatan tangkap ikan & - & 100 & - & - & - \\
\hline Peralatan pascatangkap & - & 100 & - & - & - \\
\hline
\end{tabular}




\begin{tabular}{lcclcc}
\hline Tempat penjualan (TPI) & 37,5 & 62,5 & - & - & - \\
\hline Kelompok nelayan & 37,5 & - & - & - & 62,5 \\
\hline Kredit (jika ada) & - & 25 & - & - & 75 \\
\hline Pendapatan nelayan & - & - & - & - & 100 \\
\hline Belanja makanan & 100 & - & - & - & - \\
\hline Belanja pakaian & 100 & - & - & - & - \\
\hline Perumahan & - & 100 & - & - & - \\
\hline Pendidikan & - & - & 100 & 100 & - \\
\hline
\end{tabular}

Keterangan : Ada 8 juragan darat semuanya laki-laki.

Mereka lebih memahami dan memiliki pengalaman yang penting terhadap peralatan tangkap ikan dan peralatan pasca tangkap ikan. Demikian juga dalam hal peruahan dan penjualan di tempat penjualan ikan memberikan manfaat bagi nelayan laki-laki. Mereka dapat memiliki perumahan yang layak huni dan dapat meningkatkan keahlian dalam jual beli ikan di tempat pelelangan. Sedangkan nelayan perempuan memperoleh pengalaman berharga dan merasakan manfaat yang besar karena mereka menjadi lihai dalam berbelanja makanan dan pakaian.

Manfaat yang dapat dirasakan oleh nelayan perempuan dan laki-laki sebagai juragan darat adalah membaiknya pendapan mereka dari hari ke hari. Manfaat lainnya adalah sebagai anggota kelompok nelayan, mereka dapat memperoleh imformasi yang berharga selama keberadaannya di kelompok tersebut. Dan manfaat yang paling dirasakan oleh keluarga nelayan adalah tingkat pendidikan anak laki-laki dan perempuan menjadi lebih baik dibandingkan orang tua mereka.

Tabel 27. Manfaat dan Dampak Sumberdaya Juragan Laut

\begin{tabular}{lccccc}
\hline \multicolumn{1}{c}{ Sumberdaya } & $\begin{array}{c}\text { Nelayan } \\
\text { Perempuan } \\
\%\end{array}$ & $\begin{array}{c}\text { Nelayan } \\
\text { Laki-laki } \\
\%\end{array}$ & $\begin{array}{c}\text { Anak } \\
\text { Perempuan } \\
\%\end{array}$ & $\begin{array}{c}\text { Anak } \\
\text { Laki-laki } \\
\%\end{array}$ & $\begin{array}{c}\text { Bersama } \\
\%\end{array}$ \\
\hline Peralatan tangkap ikan & - & 100 & - & - & - \\
\hline Peralatan pascatangkap & - & 100 & - & - & - \\
\hline Tempat penjualan (TPI) & - & - & - & - & - \\
\hline Kelompok nelayan & - & 100 & - & - & - \\
\hline Kredit (jika ada) & - & 100 & - & - & - \\
\hline Pendapatan nelayan & - & 10 & - & - & 90 \\
\hline Belanja makanan & 100 & - & - & - & - \\
\hline Belanja pakaian & 100 & - & - & - & - \\
\hline Perumahan & - & 100 & - & - & - \\
\hline Pendidikan & - & - & 100 & 100 & - \\
\hline
\end{tabular}

Keterangan : Ada 10 juragan laut semuanya laki-laki.

Manfaat yang hampir sama juga dirasakan oleh juragan laut atau juru mudi. Nelayan perempuan menikmati manfaat dalam hal keterampilan belanja makanan dan belanja pakaian. Sementara itu manfaat yang dirasakan oleh nelayan laki-laki meliputi pengetahuan dalam hal peralatan tangkap ikan, peralatan pasca tangkap, kelompok nelayan, kredit dan pendapatan. Anak laki-laki dan perempuan merasakan manfaat dalam hal perbaikan tingkat pendidikan mereka. Secara keseluruhan manfaat yang dirasakan oleh juragan laut adalah membaiknya pendapatan. 
Tabel 28. Manfaat dan Dampak Sumberdaya ABK

\begin{tabular}{lccccc}
\hline \multicolumn{1}{c}{ Sumberdaya } & $\begin{array}{c}\text { Istri ABK } \\
\%\end{array}$ & $\begin{array}{c}\text { ABK } \\
\%\end{array}$ & $\begin{array}{c}\text { Anak } \\
\text { Perempuan } \\
\%\end{array}$ & $\begin{array}{c}\text { Anak } \\
\text { Laki-laki } \\
\%\end{array}$ & $\begin{array}{c}\text { Bersama } \\
\%\end{array}$ \\
\hline Peralatan tangkap ikan & - & 100 & - & - & - \\
\hline Peralatan pasca tangkap & - & 100 & - & - & - \\
\hline Tempat penjualan (TPI) & - & 100 & - & - & - \\
\hline Kelompok nelayan & - & - & - & - & - \\
\hline Kredit (jika ada) & - & 100 & - & - & - \\
\hline Pendapatan nelayan & - & 100 & - & - & - \\
\hline Belanja makanan & 100 & - & - & - & - \\
\hline Belanja pakaian & 100 & - & - & - & - \\
\hline Perumahan & - & 100 & - & - & - \\
\hline Pendidikan & - & - & 100 & 100 & \\
\hline
\end{tabular}

Keterangan : Ada 16 ABK semuanya laki-laki

Bagi para ABK aktivitas dan rakses yang dimiliki memberikan manfaat terhadap peningkatan pengetahuan dan keterampilan pada peralatan alat tangkap ikan dan peralatan pasca tangkap. Dan ABK juga menjadi paham seluk beluk kegiatan ditempat pelelangan ikan, pemaafaatn kredit dan peningkatan pendapatan. Sementara itu istri ABK menjadi lebih mahir dalam hal belanja makanan dan belanja pakaian karena aktivitas mereka terkonsentrasi di rumah. Akhirnya ABK juga merasakan manfaat terhadap peningkatan pendapatan mereka khususnya pada musim panen. Perumahan ABK menjadi lebih baik dan pendidikan anak laki-laki maupun perempuan ABK mengalami perbaikan.

Tabel 29. Manfaat dan Dampak Sumberdaya Blantik

\begin{tabular}{lcccc}
\hline Sumberdaya & $\begin{array}{c}\text { Blantik } \\
\text { perempuan }\end{array}$ & $\begin{array}{c}\text { Blantik } \\
\text { laki-laki }\end{array}$ & $\begin{array}{c}\text { Anak } \\
\text { peremuan }\end{array}$ & $\begin{array}{c}\text { Anak } \\
\text { laki-laki }\end{array}$ \\
\cline { 2 - 5 } & $\%$ & $\%$ & $\%$ & $\%$ \\
\hline Peralatan tangkap ikan & - & - & - & - \\
\hline Peralatan pasca tangkap & - & - & - & - \\
\hline Tempat penjualan (TPI) & 37,5 & 62,5 & - & - \\
\hline Kelompok nelayan & - & - & - & - \\
\hline Kredit (jika ada) & - & 100 & - & - \\
\hline Pendapatan nelayan & 100 & 100 & - & - \\
\hline Belanja makanan & 100 & - & - & - \\
\hline Belanja pakaian & 100 & - & - & - \\
\hline Perumahan & - & 100 & - & 100 \\
\hline Pendidikan & - & - & 100 & \\
\hline
\end{tabular}

Keterangan : Ada 6 blantik peremuan dan 2 blantik laki-laki

Blantik perempuan atau pedagang di PPI Pondok Dadap juga memperoleh manfaat dari kegiatan jual beli di tempat pelelangan ikan karena pendapatan mereka menjadi lebih baik, belanja makanan dan pakaian juga mengalami perbaikan. Sementara itu blantik laki-laki merasakan manfaat dari tempat penjualan ikan, pemanfaatan kredit, pendapatan, perumahan. Sementara itu tingkat pendidikan anak lakilaki dan perempuan mereka relatif lebih baik karena adanya kesadaran blantik untuk menyekolahkan anakanak mereka ke jenjang pendidikan yang lebih baik. 
Tabel 30. Manfaat dan Dampak Sumberdaya Bagi Pengambek

\begin{tabular}{lcccc}
\hline \multirow{2}{*}{ Sumberdaya } & $\begin{array}{c}\text { Pengambek } \\
\text { perempuan }\end{array}$ & $\begin{array}{c}\text { Pengambek } \\
\text { Laki-laki }\end{array}$ & $\begin{array}{c}\text { Anak } \\
\text { perempuan }\end{array}$ & $\begin{array}{c}\text { Anak } \\
\text { Laki-laki }\end{array}$ \\
\cline { 2 - 5 } & $\%$ & $\%$ & $\%$ & $\%$ \\
\hline Tempat penjualan (TPI) & 33,3 & 66,6 & - & - \\
\hline Pendapatan pengambek & 33,3 & 66,6 & 100,0 & 100,0 \\
\hline Belanja makanan & 33,3 & 66,6 & 100,0 & 100,0 \\
\hline Belanja pakaian & 33,3 & 66,6 & 100,0 & 100,0 \\
\hline Perumahan & 33,3 & 66,6 & 100,0 & 100,0 \\
\hline Pendidikan & - & - & 100,0 & 100,0 \\
\hline
\end{tabular}

Keterangan : Ada 1 pengabek perempuan dan 2 pengambek laki-laki

Sementara itu bagi pengambek perempuan manfaat yang dirasakan dari aktivitas dan akses mereka terhadap sumberdaya perikanan adalah memiliki pekerjaan di tempat penjualan ikan, pendapatan mereka menjadi bertambah, belanja makanan, pakaian, dan perumahan menjadi lebih baik lagi. Sementara itu pengambek laki-laki juga memperoleh manfaat yang sama dengan pengambek perempuan, hanya saja pengambek laki-laki menikmati manfaat lebih besar karena jumlah mereka lebih banyak dan dapat menguasai sumberdaya lebih besar. Sementara anak laki-laki dan perempuan pengambek juga dapat menikmati makanan dan pakaian yang lebih bangus, dan dapat berteduh di rumah yang layak serta memiliki pendidikan yang lebih baik.

Secara umum manfaat yang diperoleh pengambek laki-laki lebih besar daripada pengambek perempuan dari kegiatan di PPI Pondok Dadap, di sisi lain manfaat bagi anak laki-laki dan perepuan para pengambek dirasakan seimbang.

Tabel 31. Manfaat dan Dampak Sumberdaya Pengolah

\begin{tabular}{lcccc}
\hline \multicolumn{1}{c}{ Sumberdaya } & $\begin{array}{c}\text { Pengolah } \\
\text { perempuan }\end{array}$ & $\begin{array}{c}\text { Pengolah } \\
\text { laki-laki }\end{array}$ & $\begin{array}{c}\text { Anak } \\
\text { perempuan }\end{array}$ & $\begin{array}{c}\text { Anak } \\
\text { laki-laki }\end{array}$ \\
\cline { 2 - 5 } & $\%$ & $\%$ & $\%$ & $\%$ \\
\hline Tempat lelang (TPI) & 100,0 & - & 40,0 & 20,0 \\
\hline Peralatan produksi & 100,0 & - & - & - \\
\hline Bahan olahan & 100,0 & - & - & - \\
\hline Kelompok Wanita N & 100,0 & - & - & - \\
\hline LEPM & 100,0 & - & - & - \\
\hline Pasar & 100,0 & - & - & - \\
\hline Kelompok nelayan & 100,0 & - & - & - \\
\hline Kredit & - & 100,0 & - & - \\
\hline Pendapatan pengolah & 100,0 & - & 100,0 & 100,0 \\
\hline Belanja makanan & - & 100,0 & 100,0 & 100,0 \\
\hline Belanja pakaian & - & 100,0 & 100,0 & 100,0 \\
\hline Perumahan & 100,0 & - & 100,0 & 100,0 \\
\hline Pendidikan & - & - & 100,0 & 100,0 \\
\hline
\end{tabular}

Keterangan : Ada 5 pengolah semuanya perempuan.

Sebagaimana manfaat yang dirasakan oleh juragan darat, ABK, blantik, dan pengambek, para pengolah ikan laut juga merasakan adanya manfaat dari aktivitas dan kesempatan akses mereka terhadap sumberdaya perikanan. Apalagi para pengolah didominasi para perempuan sehingga dalam hal ini manfaat yang paling besar dirasakan oleh pengolah perempuan daripada laki-laki. Manfaatyang jelas-jelas dirasakan oleh pengolah perempuan adalah mereka menjadi memiliki pekerjaan karena adanya PPI, mereka memiliki peralatan produksi pengolah ikan dengan teknologi modern, mendapatkan bahan olahan dengan 
mudah, dapat memanfaatkan teknologo pengolahan yang lebih modern, dapat merasakan manfaat adanya lembaga pemberi kredit (LPEM), meningkatkan pendapatan, dan perumahan pengolah bertmbah lebih baik. Sedangkan pengolah laki-laki mendapatkan manfaat berupa pendapatan meningkat,belanja makanan dan pakaian menjadi mudah, dan dapat menikmati kredit dari KUD. SementR itu anak laki-laki dan perempuan para pengolah memperoleh manfaat berupa perbaikan kualitas makanan dan pakaian mereka dan pendidikan anak-anak para pengolah relative lebih baik.

Secara umum dapat dikatakan bahwa semua pelaku ( juragan darat, juragan laut, ABK, blantik, pengambek dan pengolah ikan) baik laki - laki maupun perempuan di PPI Pondok dadap merasakan manfaat dari aktivitas dan akses mereka terhadap sumberdaa perikanan.

Apabila dikaji dari sudut dampak, maka aktivitas nelayan yang sangat sibuk dan menyita banyak waktu untuk mencari ikan di laut dan mengurus perahu yang menuntut ketelitian dan keterampilan, maka sebagaimana dituturkan oleh para nelayan sendiri, mereka juga mengeluh terhadap pendamping proses belajar anak-anaknya di rumah.

Mereka juga kurang dapat menjaga kebersihan lingkungan rumah secara baik. Dengan demikian dapat dinyatakan bahwa dampak utama dari kehidupan keluarga nelayan adalah kurangnya perhatian pendamping proses belajar anak-anak di rumah dan kurang terjaganya kebersihan lingkungan rumah.

\section{Model pembinaan perempuan Nelayan Traditional}

Rumusan metode pembinaan perempuan nelayan traditional disusun melalui Focussed Group Duscussion (FGD). Peserta FGD adalah pihak-pihak yang terkait dengan aktivitas nelayan traditional (stake holder) meiputi : Tim PSWK, Petugas PPI, perwakilan nelayan traditional (juragan, ABK, blantik, pengambek, pengolah), petugas TPI, ketua kelompok nelayan, dan pemerintah desa, setempat. Rumusan pembinaan di rumuskan difokuskan pada pembinaan keluarga dan pembinaan usaha.

\section{Pembinaan Keluarga}

Data penelitian menunjukan bahwa pada keluarga nelayan terdapat aktivitas yang cukup padat. Keluarga sering ditinggal salah satu atau kedua orang tua. Suami seharian di TPI. Pada keluarga ABK, beberapa ada yang ditinggalkan istri menjadi TKW. Konsekuensi keluarga demikian adalah adanya tanggung jawab yang berat bagi perempuan untuk mendidik anak di rumah, bahkan ada anak yang terlantar dari perhatian ibu dan ayahnya. Padahal secara umum motivasi pendidikan keluarga nelayan masih rendah dan terbatas sarana pendidikan serta lokasiyang jauh dari kota ikut memperparah kondisi pendidikan anakanak nelayan.

Berdasarkan keadaan tersebut, model pebinaan keluarga difokuskan pada pendidikan keluarga. Secara singkat model pembinaan pada keluarga nelayan tersebut dirinci sebagai berikut:

- Bentuk: pendidikan informal

- Waktu: sekali dalam seminggu dengan jadwal yang berbeda untuk memberikan waktu pilihan antar kelompok.

- Materi: pembinaan anak, kesehatan, sanitasi lingkungan, kesehatan keluarga,terwujud keadilan dan kesetaraan gender.

\section{Pembinaan Usaha}

Berdasarkan data penelitian terdapat tiga macam usaha pengolahan ikan yaiu abon, pindang dan ikan asin. Temuan lapang menunjukkan persoalan usaha terjadi hanya pada abon yaitu persoalan kualitas abon dan sulitnya pemasaran. Sedangkan pada pengolah pindang dan ikan asin tidak ada persoalan usaha karena sudah berjalan lancer, namun persoalan mereka adalah pada pengelolaan sanitasi lingkungan. Oleh karena itu pembinaan usaha difokuskan pada pengolah abon. Sedangkan pembinaan keluarga pengolah pindang dan ikan asin bersamaan dengan pembinaan keluarga.

Model pebinaan usaha nelayan dirinci sebagai berikut:

Bentuk : pendidikan informal

Sasaran : keluarga pengolah abon (laki-laki dan perempuan bersama)

Waktu : sekali dalam seminggu. 
Materi : manajemen usaha, teknik pengolahan dan pengeasan, manajemen pemasaran, membangun jaringan usaha, promosi dan mencari pelanggan.

Target : terwujudnya manajemen usaha yang professional, kualitas produk yang baiki, ada jaringan pemasarang ke kota, terwujudnya pembagian kerja dalam usaha dan keluarga yang seimbang antara laki-laki dan perempuan.

\section{Kesimpulan}

Berdasarkan hasil penelitian diperoleh kesimpulan sebagai berikut:

1. Aktivitas nelayan pada kegiatan melaut semuanya dilakukan oleh laki-laki. Keterlibatan perempuan hanya pada persiapan bekal makan, dan kegiatan pasca tangkap yaitu pelelangan. Pada katagori blantik dan pengambek, peran perempuan yang dominan pada aktivitas trasaksi ikan di TPI. Selebihnya peran perempuan juga dominan pada pekerjaan domestic. Jadi disini masih ada pembagian kerja gender berdasarkan kepantasan pekerjaan perempuan dan laki-laki.

2. Akses dan kontrol laki-laki dominan pada sumberdaya penangkapan ikan dan kelompok nelayan. Akses dan control perempuan dominan pada sumberdaya domestic dan sumberdaya pengolahan ikan.

3 Manfaat sumberdaya nelayan sudah dinikmati bersama diantara anggota keluarga nelayan, baik lakilaki maupun perempuan. Dampak yang dirasakan dari sibuknya aktivitas nelayan adalah terlantarnya pendidikan anak dan perhatian pada kesehatan dan sanitasi lingkungan.

4 Model pembinaan nelayan terdiri dari pembinaan keluarga dan pembinaan usaha. Model pembinaan keluarga difokuskan pada pembinaan anak, kesehatan, sanitasi lingkungan dan kesetaraan gender. Pembinaan usaha pada pengelola abon terdiri dari manajemen usaha, teknik pengolahan dan pengemasan, manajemen pemasaran, membangun jaringan usaha, promosi dan mencari pelanggan.

\section{Saran}

Berdasarkan hasil penelitian dikemukakan saran sebagai berikut:

1 Pembinaan keluarga nelayan perlu ditingkatkan agar terwujud motivasi pendidikan anak yang lebih baik, peningkatan kesehatan keluarga, terwujudnya keadilan dan kesetaraan gender.

2 Pembinaan usaha pengolahan ikan perlu ditingkatkan agar terwujud manajemen usaha yang professional, kualitas produk yang baik, dan jaringan pemasaran kekota, terwujudnya pembagian kerja dalam usaha dan keluarga yang seimbang antara laki-laki dan perempuan.

\section{Daftar Pustaka}

Anonim, 1997a. Perikanan Indonesia Dalam Angka dan Fakta. Primadona Perikanan. Edisi SeptemberOktober. Tahun ke-III. Jakarta.

Anonim, 1997b. Mengungkap Sumberdaya Manusia (SDM) Perikanan Indonesia. Primadona Perikanan. Edisi September-Oktober. Tahun ke-III. Jakarta

Anonim, 2004. http://www.e-ti.com/ensiklopedi/r/rokhmin-dahuri/wawancara.shtml

Anonim, 2004. http://www.pikiran-rakyat.com/cetak/0403/12/04x3.htm

Patricia Taura, 1997. SPC Women's Fisheries Developmen Project Marshall Islands Mission Report. SPC Women's Fisheries Developmen Officer.

Pudjiwati Sajogyo, 1983. Peranan Wanita dalam Perkembangan Masyarakat Desa. Kerjasama Yayasan Ilmu-Ilmu Sosial (YIIS) dengan CV. Rajawali. Jakarta.

Simatauw Meentje, dkk. 2001. Gender dan Pengolahan Sumberdaya Alam. Yayasan Pikul. Yogyakarta.

Sri Murni Soenarno, 2004. Pembedayaan Wanita Nelayan dalam Pemanfaatan Sumberdaya Alam Secara Lestari. www.dkp.go.id 
Taufiq, M. 1998. Pemberdayaan Koperasi, Pengusaha Kecil dan Menengah Melalui Program Mutu Terpadu Usaha perikanan Guna Meningkatkan Kesejahteraan Nelayan dan Petani Ikan. Seminar Nasional Perikanan Indonesia. Senat Mahasiswa Perikanan Universitas Brawijaya Malang.

Rahayu Relawati dkk, 2001. Studi Gender pada Aktivitas Pasca-Produksi Hortikultura Unggulan di Batu: Studi Kajian Wanita- DIKTI Th 2001

Rahayu Relawati, 2003. Analisis Gender pada Wirausaha Agribisnis (Studi Kasus Pada Wirausaha Florist di Kota Malang): Studi Kajian Wanita-DIKTI Th 2003. 